\title{
Alignment of TQM in the Higher Education context
}

\section{Everard VAN KEMENADE}

Expert Quality Assurance, Netherlands

\begin{abstract}
Purpose - To adjust the concept of Total Quality Management to and make it fit for use in Higher Education Institutes.

Design/methodology/approach - The article describes the results of a design science research. Based on experiences in Egypt and the Netherlands the characteristics of Higher education are defined as well as the specifics of educational processes. These lead to a translation of TQM in educational terms.
\end{abstract}

Findings - The experiences result in a model that can be used as framework to implement TQM in Higher Education Institutes

Research limitations/implications - The experiences that form the base for the design are limited to two countries, with two different cultures. There is no evidence concerning the use of the model in every country in the world.

Originality/value - It is known that there have been many initiatives to implement TQM in Higher Education. The combination with Quality Management in Teaching and Learning models (Transformative Model, An Engagement Model of Program Quality , University of Learning Model, A Model for a Responsive University) is scarce, as well as application in two such different countries.

Keywords - Total Quality Management, Quality Management in teaching and learning, Holistic quality model for Higher Education 


\section{Introduction}

Total Quality Management and its European equivalent the European Foundation for Quality Management Excellence Model started in Western countries almost 50 years ago and generated great interest in most firms in the beginning. Grant et al. (1994), Dalrymple \& Drew (2000) and Young et al. (2006) emphasise that TQM means a paradigm shift. One of the most distinguishing factors of TQM companies mentioned is the centrality of the human or 'soft' factor in the way to continuous improvement.

TQM had its ups and downs (Hermel,1997). Interest declined in the end of the eighties and revived in the beginning of the nineties of last century. At the moment TQM is still practice, often next to new methods like lean management and Six Sigma. Although research on Total Quality Management reports mixed results, the main tendency is that TQM is said to work, that it actually improves the quality of the business. "Continuous improvement and problem prevention significantly enhance job satisfaction and organizational commitment" (Karia and Assaari, 2006). "Where teamwork was perceived as a dominant TQM practice, improvements in job satisfaction levels were significant" (Ooi et al., 2007).TQM has been successfully implemented in different contexts. In manufacturing as well as in services (see e.g. the literature review of Sureshchandar et al, 2001). In Western countries as well as in emerging countries (Martin and Weill, 2000) or in Arabic countries like Qatar (A1Khalifa and Aspinwall, 2000 ), Yemen (Al-Zamany et al., 2000) and Egypt (e.g. Salaheldin, 2003; Elghamrawy and Shibayama, 2008 ).

It is important to know, what factors influence the success of TQM. One of the main critical success factors for TQM implementation reported in scientific research is that senior management should be committed (Evans, 1995; Chowdury et al, 2007; 
Soltani et al., 2008; Bayaktar et al., 2008; Bin et al, 2009). Hirtz et al. (2007) specify this (for administrative/service organizations) by saying that transformational leadership appears to be critical in the successful implementation of quality management. Furthermore there is broad consensus that employees need to be involved (Gatchalian, 1997; Krüger,1998; Sun et al, 2000; Yen, 2003; Rahman, 2004; Hoogervorst et al., 2005; Ooi et al., 2007; Chowdury et al., 2007; Bayaktar et al., 2008; Bin et al., 2009) or that there should be strong internal motivation (Wiele et al, 2000). These factors can be summarized in the need for Commitment. There should be emotional involvement to the implementation (Wiele et al, 2000) or -in a broader sense- a quality Culture (Fuchs 1993).

Fuchs (1993) adds the lack of focus on strategic planning as roadblock for companies that strive to use TQM for competitive advantage. Bayaktar et al. (2008) mention the importance of a vision. We here call this factor Concept, that includes a company's mission, values and vision.

Commitment, Culture and Concept are the drivers for the Paradigm Change, if the Company and its TQM system fits to the Context. Sousa \& Voss (2001, strongly suggest that process quality management practices are contingent on a plant's manufacturing strategy. They argue, that rigorous academic studies have raised doubts as to the universal validity of the whole set of quality management practices. Conti (2007) calls this the contingency view and states that adaptation of the model to the characteristics of the organization should be always pursued. This leads us to our theoretical construct, The Van K. Esawi Tower of TQM, see figure 1. 


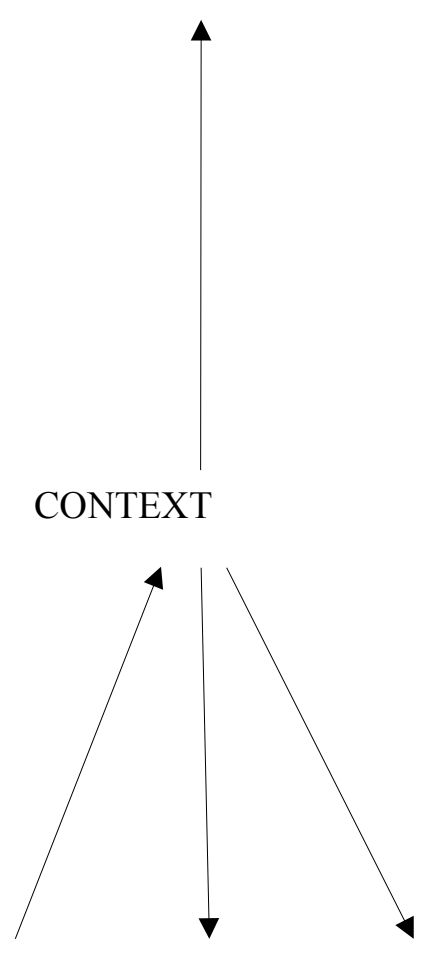

\section{COMMITMENT}

CULTURE

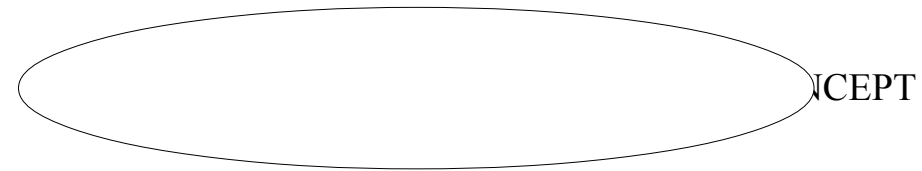

Figure 1: The Van K. Esawi Tower of TQM

\section{Definitions}

Concept:Vision, mission and values of the organization.

Commitment: the state of being obligated or emotionally impelled top management and employees are in.

Culture: the way we do things around here, code of conduct.

Change: an act or process through which something becomes 


\section{Quality and higher education}

All over the world the pressure on Higher Education institutions caused by expansion and increase in student numbers, cultural diversification, cuts in funding levels and accelerated changes reflected drastically in the society needs and marketplace requirements. To find answers to these challenges management cultures from the business and manufacturing industry are imported into the public sector generally, and Higher Education in particular. This constitutes the challenges inherent in defining, developing, and demonstrating a Total Quality Management model in colleges and universities.

TQM has been implemented in educational settings with mixed success (Bergquist et al., 2005). The resistance is strong (Koch and Fischer, 1998; Temple, 2005, Minelli et al, 2008 ). That leads Harvey to conclude in 1995: "There is no overwhelming evidence that, in the higher education context, TQM does you good". Sirvancy (2004) focuses on the difficulties, but stays positive.

Weller and Hartley (1994) stress the usefulness of TQM for higher education. Pupius (2002) and Kemenade et al. (2004) developed models for higher education based on the European Foundation for Quality Management Excellence Model. The latter, originally Dutch, has been translated into English, German, Czech, Latvian, French, Spanish and even Vietnamese. Motwani and Kumar (1997) report improved communication, higher employee morale, increased productivity, improved process efficiency and reductions in defects and costs. Lagrosen (1999) mentions: greater job satisfaction, better communication, enhanced co-operation between departments, and improved leadership. Saktival et al. (2000), Wiklund et al.(2003), Hides et al. (2004), Agarwal et al. (2011) all report positive results as well. 
Critical factors mentioned in the Higher Education context fit into the Van K. Elsawi Tower. Many research states the importance of commitment of the top management (Schaik et al., 1988, Sakthivel, 2000; Kemenade, 2009; Kemenade and Hardjono, 2010; Kemenade et al. 2011). Also commitment of educational staff is mentioned (e.g. Crawford and Shutler, 1999; Kemenade, 2009). The culture is important (e.g. control and improvement should be separated, Kemenade 2009 and 2010). Ali et al. (2010) mention visionary leadership (part of "concept") as one of the critical success factors. One of the main issues in the research to make TQM in Higher Education work, it should be adapted to the context (Taylor and Hill, 1991; Kwan, 1996; Schaik et al., 1998; Zink and Voss, 1999; Helms et al. 2001, Osseo-Asare and Longbottom, 2002; Pupius, 2002; Davies, 2004; Carter and Swanwick, 2006).

The argument sought here is to define the total quality management model that can be applicable in the higher education context.

\section{Adjustment to the educational context}

An 'ideal educational system' should incorporate the following 'learning insights':

(1) Learning is about transforming the student is into a flexible thinker,

(2) Learning occurs all the time; all situations are therefore a learning opportunity,

(3) Learning occurs best in the context of a compelling present problem,

(4) Frequent feedback reinforces learning effects,

(5) Learning occurs best in an interpersonal context, working harmoniously with others, etc.

However, the problem lies in the very fact that at the organization level, a typical university in the many countries is not yet ready to respond to the above-mentioned requirements. Their pattern of approach seems to be characterized by the following: 
(6) Academic programs tend not be student-centred,

(7) Lack of systemic thinking, consistent leadership for change and continuing approach for improvement.

As a result, curriculum and instructions are not clearly conducive for producing learning gains, as characterized by a debilitating fragmentation of learning experiences. Instructional paradigms which feature only individual work undermine the positive results on the effectiveness of collaborative learning. There is minimal feedback on performance. In addition to its focus on the continuous improvement principle, TQM also focuses on the principle of customer satisfaction. Although some academics are uncomfortable with the idea of students as customers, few would argue that we listen enough to our students, and fewer still would assert that we cannot improve our programs and services by seeking evaluations from our students.

That is why the enthusiasm of the academics to TQM has never been very high. Therefore the only logical conclusion one can arrive at in relation to a model for quality management in higher education is that it would have to be more holistic to flexibly address service and pedagogical aspects uniquely.

The need for distinct approaches to the service and teaching areas of higher education proposed is based on their distinctiveness of emphasis. In the service areas student is clearly the customer and is the focus of all processes. In the teaching and research function students play the key role of a participant and the focus is on the attribute of their learning, as determined by:

1. The global parameters of content and resources governing the curriculum design, and

2. The subtle parameters of delivery and assessment governing the 'enhancement' of the learner. 
TQM addresses the service areas, focusing on the products of delivery by measuring, monitoring and continuously improving the processes. Quality Management of Teaching and Learning (QMTL), on the other hand, focuses on the empowerment of the course team across all the boundaries to facilitate a dialogue centred on learning. The techniques of TQM are well understood and documented in the industry practice, whereas those of QMTL are rooted in the educational research literature, illustrated initially on the basis of a synthesis of the following four models (Transformative Model ,An Engagement Model of Program Quality, University of Learning Model, A Model for a Responsive University).

In spite of the structural difference in the scope of the two models, there is a substantial commonality of requirements in the implementation phase. First of all, their focus on students albeit to differing levels of subtlety. Secondly, at the operational level, collaboration is a key requirement in both the models although the fields of interaction may vary to a large extent. Both the models also require a visible commitment and support from the senior management to effectively continue to flourish. Thus, by and large, the pattern of interaction and governance required for both the approaches is the same. Al-Mazrooa et al. (2010) state that "While each model cited in the previous section has its own unique perspective on educational quality in a university, it is necessary to examine them more closely to see if they can be described by a generic model for quality management".

Having laid out an exploration of both the above-mentioned models, we designed a comprehensive quality model that is characterized by:

- A reconciliation or sound blend of TQM and quality models (Transformative Model, An Engagement Model of Program Quality, University of Learning Model, A Model 
for a Responsive University ), based on more integrated and interdependent system or process.

- Embracing the cultural and contextual variations through developing a conducive culture and empowering environment adaptive to new developments and changes.

- Mandatory Assessment and selection process pretesting the program entrants (students) to measure their background knowledge \& skills to fit with the selected programs requirements.

- A focus on the marketplace requirements to ensure the responsiveness of programs outcomes and students' knowledge \& skills are responsive to these demands and requirements.

- Constant feedback \& evaluation of all components for perusing an overall Continuing Improvement.

- Effective Institutional engagement with community stresses its external relationship and interaction.

The comprehensive quality model has 6 components embedded in the context, culture and commitment: educational inputs, educational objectives.

\section{(1) Educational Inputs}

1. Diverse and engaged participants highlighting the pivotal role that the faculty, students and leaders play. Assessing their backgrounds, traits and needs using appropriate selection tools are mandatory.

2. Leadership defining the company's concept (mission, values and vision).

3. Adequate educational resources: nature of facilities and support for students, faculty and basic infrastructure. 


\section{(2) Educational Objectives}

4. Statements that describe career and professional accomplishments that the learning is preparing graduates to achieve. (National) Academic Reference Standards and intended learning outcomes based on external context analysis. Intended Learning Outcomes are statements that describe what students are expected to learn and be able to apply by the time of graduation (knowledge, skills and attitude).

\section{(3) Connected Program Requirements}

5. Curriculum development and course development.

\section{(4) Student Experience}

6. Interactive teaching and learning classrooms experience.

7. Interpersonal context

8. Out- of - class experiences including: co-curricula, internships \& support services.

9. Research

\section{(5) Learning Outcomes}

The learning outcomes are subject to Performance criteria that are specific measurable statements identifying the performance(s) required to meet the outcome, confirmable through evidence (e.g in the form of the quality of the thesis).

10. External relationships including social engagement with communities.

11. Achieving the stated outcomes of the learning process and reaching out to the community through effective relationship and participation will help,among other things in boosting the organizational ranking(employer ranking) that consider measures of research excellence and/or influence and social engagement, student choices, eventual success and others. 


\section{(6) Evaluation and continuous improvement}

12. Assess and evaluate: collection, analysis and interpretation of evidence.

13. Feedback for continuous improvement.

\section{Conclusion}

The framework developed can be used as a guideline for self assessment. On each of the 6 components within the culture, context and commitment a Deming cycle can be applied. It will be familiar to the academic and evoke less resistance than the manufacturing terminology like "processes", "customers" and "suppliers". Experiences with similar adjustments (Schaik et al. 1998; Kemenade et al., 2004; Shaktivel and Raju, 2006; Pupius, 2007) support this proposition. 


\section{Framework of Quality Model in Higher Education}

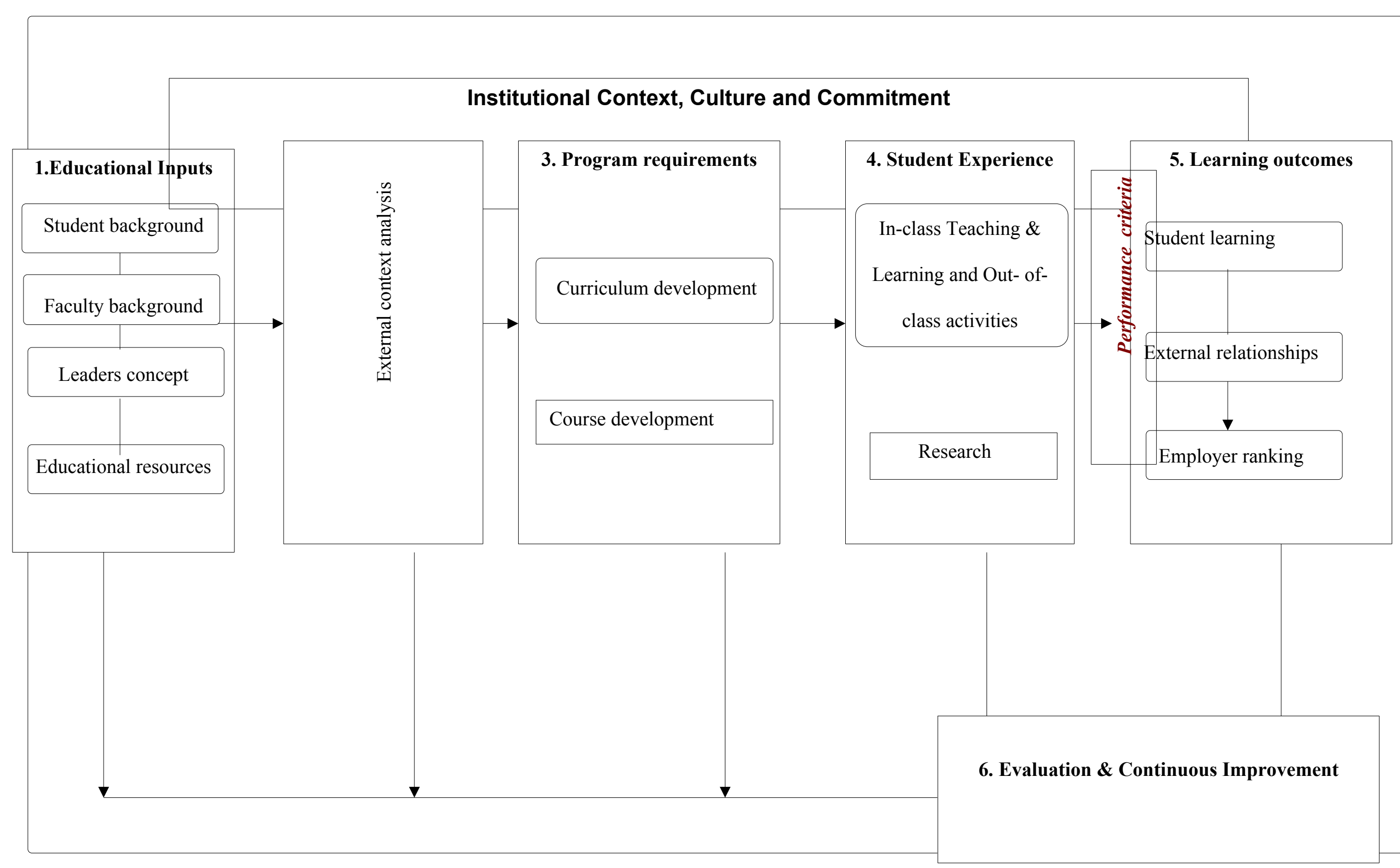




\section{References}

1. Agarwal P.K., Kumar,P., Swati G. and Tyagi A.K. (2011), Implementing Total Quality Management in Professional Educational Institutes in India, Advances In Management, Vol. 4, No. 4, pp. 18-22

2. Ali, N.A., Mahat, F. and Zairi, M. (2010) Testing the criticality of HR-TQM factors in the Malaysian Higher Education context, Total Quality Management, Vol. 21, No. 11. Pp. 1177-1188

3. Al-khalifa K. N and Aspinwall E. M. (2000), The development of Total Quality Management in Qatar, The TQM Magazine, Vol. 12 . No. 3 , pp. 194-204

4. Al-Mazrooa, A, El-Deek, B. (2010), Applying the Total Quality Management (TQM) Model and the Holistic Model for Quality Management in Higher education, pros and Cons, Research Journal of Medical Sciences, Vol 4. No 2, pp. 102-106

5. Bayraktar,E., Tatoglu,E. and Zaim, S. (2008) An instrument for measuring the critical

6. factors of TQM in Turkish Higher Education, Total Quality Management, Vol. 19, No. 6, pp. 551-574

7. Bergquist, B., Fredrickson M. and and Svensson M. (2005), TQM: terrific quality marvel or tragic quality malpractice? The TQM Magazine, Vol. 17 No. 4, pp. 309321

8. Bin Abdullah, M.M., Uli J. and Tari, J.J. (2009) The relationship of performance with soft factors and quality improvement, Total Quality Management, Vol. 20, No. 7, pp. 735-748

9. Bogue, E.G. (1998), "Quality Assurance in Higher Education: The Evolution of Systems and Design Ideals"

10. Carter, G. and Swanwick, J. (2006) Where next for Quality? Is it beyond 9 box models? World Congress for TQM. Wellington, New Zealand.

11. Conti, T. (2007), A history and review of the European Quality Award Model, The TQM Magazine, Vol. 19, No. 2, pp. 112-128 
12. Chowdhury, M., Paul H. and Das A., (2007), The Impact of Top Management Commitment on Total Quality Management Practice: An Exploratory Study in the Thai Garment Industry Global Journal of Flexible Systems Management, Vol. 8, Nos. 1 \& 2., pp 17-29

13. Crawford, L.E.D. and Shutler, P. (1999), Total Quality Management in Education: problems and issues for the classroom teacher, The International Journal of Educational Management, Vol. 13, No. 2, pp. 67-72

14. Davies, J. (2004), The implementation of the EFQM's Excellence model in academic units of UK Universities, University of Salford, $\mathrm{PhD}$ thesis

15. Elghamrawy, Tarek and Shibayama, Tomoya (2008), Total Quality Management Implementation in the Egyptian Construction Industry, Journal of Management in Engineering, Vol. 24 Issue 3, p156-161

16. Fuchs, E. (1993), Total Quality Management from the future: practices and paradigms, The Quality Management Journal, October.

17. Gatchalian M. M. (1997), People empowerment:the key to TQM success,The TQM Magazine, Vol. 9, No. 6, pp. 429-433

18. Harvey,L. (1995), Quality Assurance Systems, TQM and New Collegialism, QHE, The University of Central England, Birmingham

19. Helms, M.M., Williams, A.B. and Nixon, J.C. (2001), TQM principles and their relevance to higher education: the question of tenure and post-tenure review, The International Journal of Educational Management, Vol. 15, No. 7, pp. 322-331

20. Hides, M.T., Davies, J. And Jackson, S. (2004), Implementation of EFQM excellence model self-assessment in the UK higher Education sector - lessons learned from other sectors, The TQM Magazine, Vol. 16, No 3 , pp. 194-201

21. Hirtz, P.D., Murray, S.L. and Riordan, C.A. (2007), The Effects of Leadership on Quality, Engineering Management Journal, Vol. 19, No. 1, pp.22-27

22. Holmes, G. and Mc. Elwee, G. (1995), Total quality management in higher education: how to approach human resource management The TQM Magazine, Volume 7, No. 6, pp. 5-10 
23. Hoogervorst J.A.P. , Koopman P.L. and van der Flier H. (2005), Total quality management. The need for an employee-centred, coherent approach The TQM Magazine, Vol. 17 No. 1, pp. 92-106

24. Iman H . Ahmad Al Sharif, " The Role Self Assessment in Architectural Education Quality "- a thesis submitted for the Master of Science in architectureCairo University ,2009.

25. Karia N. \&Assaari, M.H.A.H. (2006), The effects of total quality management practices on employees' work-related attitudes, The TQM Magazine, Vol. 18 No. 1, pp. 30-43

26. Koch, J. and Fisher, J. (1998), "'Higher Education and total quality management", Total Quality

27. Management, Vol. 9 No. 8, p. 659.

28. Beck D. \& Cowan, (1996), Spiral Dynamics, Malden, Blackwell Publishers

29. Evans, R. (1995), In defence of TQM, The TQM Magazine,Vol. 7 • No. 1, pp. $5-$ 6

30. Hermel, P. (1997), The new faces of total quality in Europe and the Us, Total Quality Management, Vol. 8, No. 4, pp. 131-143

31. Hongyi Sun, H., Hui, I.P., Tam, A.Y.K and Frick,J. (2000), Employee involvement and quality management, The TQM Magazine, Volume 12 . Number 5 . 2000 .pp. $350 \pm 354$

32. Kemenade E.A. van (eds.), Schaik, M. van; Kuiper, H., Onzenoort, J. van and Biesta, E. (2004), Method for improving the quality of higher education based on the EFQM model, Groningen/Eindhoven

33. Kemenade E.A. Van (2009) "Professionals freaking out: Accreditation in Dutch Higher Education". Total Quality Management Journal, August-issue

34. Kemenade, E.A. van (2010), Past is prologue. Know the history of quality management to achieve future success, Quality Progress, August 2010.

35. Kemenade, E. A. van and Hardjono, (2010), T.W. A Critique of the Use of Selfevaluation in a Compulsory Accreditation System, Quality in Higher Education, 16:3; pp. 257-268 
36. Kemenade, E.A. van Hardjono T. and De Vries, H. (2011), The willingness of professionals to contribute to their organisation's certification, International Journal of Quality and Reliability Management, pp. 27- 42

37. Koch,J.V., (2003), TQM? Why is its impact in Higher education so small? The TQM Magazine, Vol. 15, No.5, pp 325-333

38. Krüger, V. (1998), Total quality management and its humanistic orientation towards organisational analysis, TQM Magazine, Vol. 10 No. 4.

39. Kwan, P.Y.K. (1996), Application of total quality management in education: retrospect and prospect, The International Journal of Educational Management, Vol. 10, No. 5, pp. 25-35

40. Lagrosen, S. (1999), TQM goes to school: an effective way of improving school quality, The TQM Magazine, Vol 11:5, pp. 328-332

41. Martin, J. and Weill, M. (2000), Emerging countries and business excellence, Total Quality Management, Vol. 11, No. 4/5\&6, pp. S608-615

42. Minelli, E., Rebora, G., Turri, M. \&Huisman, J. (2006) The Impact of Research and Teaching Evaluation in Universities: Comparing an Italian and a Dutch case. Quality in Higher Education, 12, pp. 109-124.

43. Motwani, J. and Kumar, A. (1997) The need of implementing total quality management in education, The International Journal of Educational Management, Vol. 11, No. 3, pp. 131-135

44. Ooi, K.B., Baker, N.A., Arumugam,V., Vellepan, L. \&Loke, A.K.Y. (2007), Does TQM influence employees' job satisfaction? International Journal of Quality and Reliability Management,vol 24:1, pp. 62-77

45. Osseo-Asare, A.E. and Longbottom, D. (2002), The need for education and training in the use of the EFQM model for quality management in UK higher education institutes, Quality Assurance in Education, Vol. 1, No. 1, pp. 26-36

46. Peterson, G.D. and Rogers, G.M. (2009), Quality Assurance and Accreditation of Higher Education Programs- Workshop, Cairo

47. Pupius, M. (2002), Achieving Excellence in Education in Europe, Egitimide Surekli Kalite Gelistirme: Uluslararasi Basari Onekleri Sempocyumu, 6 September 2002, Istanbul, Turkey 
48. Pupius M. (2007), Quality Management in Higher Education Institutions: an Inevitable Necessity?, Hochschulrektorenkonferenz, Bonn, 8 October 2007

49. Rahman, S-U (2004), The future of TQM is past. Can TQM be resurrected?, Total Quality Management, Vol.15, No. 4, pp. 411-422

50. SakthivelP.B. , Rajendran, G. and Raju, R. (2000), TQM implementation and students' satisfaction of academic performance, The TQM Magazine, Vol. 17 No. 6, pp. 573-589

51. Sakthivel P.B. and Raju, R. (2006), Conceptualizing Total Quality Management in Engineering Education and Developing a TQM Educational Excellence Model, Total Quality Management, Vol. 17, No. 7, pp. 913-934

52. Sakthivel, P.B. (2007), Top management commitment and overall engineering education excellence, The TQM Magazine, Vol. 19 No. 3, pp. 259-273

53. Salaheldin, S.I. (2003), The implementation of TQM strategy in Egypt: a fieldforce analysis. TQM Magazine, , Vol. 15 Issue 4, p266-274

54. Schaik, M. van, Kemenade, E.A. van, Hengeveld, F. and Inklaar Y. (1998), The EFQM based method for continuous quality improvement adapted for higher Education, Paper presented at the Annual EAIR forum, 9-12 September, 1998, San Sebastian

55. Sirvancy, M.B. 2004 Critical issues for TQM implementation in Higher Education, The TQM Magazine, Vol. $16 \cdot$ No. 6, pp. 382-386

56. Solatni, E., Lai, P-C., Javadeen, S.R.S. and Gholipour T.H. (2008), A review of the theory and practice of managing TQM: An integrative framework, Total Quality Management, Vol. 19, No. 5, pp. 461-479

57. Srikanthan, G. "Developing a Model for Quality in Higher Education " 58. Srikanthan,G. and Dalrymple J. (2002), Developing a Holistic Model for Quality in Higher Education, The Seventh International Conference on ISO9000 and TQM, 2-4 April 2002, Royal Melbourne Institute of Technology, Australia 59. Sureshchandar, G.S., Chandrasekharan Rjanedran \& Anantharaman, R.Nn. (2001), A conceptual model for Total quality management in service organisations, Total Quality Management, vol. 12, no.3, pp. 343-363 
60. Taylor, W.A. and Hill, F.M. (1991), Total Quality Management in Higher Education, The International Journal of Educational Management, Vol. 5, No. 5, pp. 4-9

61. Temple, P. (2005), The EFQM Excellence Model ${ }^{\circledR}$ : Higher Education's Latest Management Fad?, Higher Education Quarterly, Vol. 59, no. 4, pp. 261-274

62. Weller, L.D. and Hartley, S.H. (1994), Total Quality management and School Restructuring:Georgia's Approach to Education Reform, Quality Assurance in Education, Vol. 2, No 2.

63. Wiele, A. Van der; Williams, A.R.T. and Dale, B.G. (2000), Total Quality Management: is it a Fad, a Fashion or a Fit?, Quality Management Journal, Vol.7, No. 2, pp.65-79

64. Wiklund, H., Klefsjö, B., Wiklund, P.S. and Edvardsson, B. (2003), "Innovation and TQM in Swedish higher education institutions: possibilities and pitfalls", The TQM Magazine,Vol. 15 No.2, pp.99-107.

65. Young, A.C.L., Cheng, T.C.E. \& Lai, K-H., (2006), An operational and institutional perspective on Total Quality Management, Production and Operations Management, vol. 15, no.1, pp. 156-170

66. Zink, K.J. and Voss, W. (1999), The new EFQM Excellence Model and its impact on Higher Education institutions, Conference proceedings from TQM for Higher Education Institutions, Higher Education Institutions and the issue of Total Quality, 301-31 August 1999, Verona, Italy, pp. 241-255 